\title{
Large Scale Low Cost Production of Submicrometric Powder Through Biomass Refinery
}

\author{
Daltro Garcia Pinattia, Rosa Ana Conte ${ }^{\mathrm{a}}$, Mônica Castoldi Borlini ${ }^{\mathrm{a}}$, \\ Benedito Celso dos Santos , Marco Aurélio Marcondesa , Isaías de Oliveira \\ Renata Garcia Oliveira Montanha ${ }^{\mathrm{a}}$, Álvaro Guedes Soares ${ }^{\mathrm{b}}$, Érica Leonor Romãob, \\ João Carlos Ferreira ${ }^{b}$, Maria Luiza Gonçalves Pereira ${ }^{\text {a }}$ \\ ${ }^{a}$ Department of Materials Engineering, FAENQUIL, C.P. 116, 12600-000 Lorena - SP, Brazil \\ ${ }^{\mathrm{b}}$ R.M. Refractory Materials Ltda., C.P. 104, 12600-000 Lorena - SP, Brazil
}

Received: November 20, 2002; Revised: May 05, 2003

\begin{abstract}
Biomass Refinery (BR) is a null pollution thermochemical sequential cracking of any biomass and some petrochemical products, which generates chemicals, liquid or solid fuels and inorganic submicrometric/nanometric powders (SM/NM) such as ashes, silica, and carbon black. The processing route, powder characterisation and addition of some ashes to red clay resulting a grès-type ceramics will be presented. Rupture strengths of the vitrified ceramics were respectively $36 \mathrm{MPa}$ for pure clay, $44 \mathrm{MPa}$ for clay $+13.5 \% \mathrm{MOL}$ ash (organic matter of municipal solid waste), $50 \mathrm{MPa}$ for clay $+20 \% \mathrm{~F}+20 \% \mathrm{CL}^{*}$ ash $(50 \% \mathrm{MOL}+50 \%$ wood) and $42 \mathrm{MPa}$ for clay $+40 \%$ feldspar (used for comparison). The reason why the BR-ashes are better than feldspar is due to their submicrometric and partially nanometric nature. The impact of BR-ash technology can be evaluated by its national potential production of $2 \times 10^{6}$ ton/year only from municipal solid waste (MSW) compared to 350,000 ton/year of national consumption. The first BR is under installation in Lorena - SP, Brazil.
\end{abstract}

Keywords: biomass refinery, submicrometric ash, vitrified ceramic, low temperature conversion

\section{Introduction}

A new concept of Biomass Refinery (BR) was developed through a matrix ordination of basic technologies in the vertical axis (mechanical, thermochemical, biological, thermoenergetic and materials) and new materials and product technologies in the horizontal axis (Fig. 1). The main points of the BR are: (1) the hard core of BR, the so-called BEM Programme (Biomass - Energy - Materials) ${ }^{1}$, is composed of six basic technologies: prehydrolysis; furfural reactor and its distillery; affluent treatment station used in closed cycle without any discharge to the environment; low temperature conversion (LTC) ${ }^{2}$; combined cycle thermoelectric plant (CCTE); and ceramic vitrification. These six technologies are complemented by three established processes (municipal solid waste selective belt, sugarcane crusher or diffusion, and chemical/mechanical pulping) and by biological processes that will not be treated in this paper because of their low possibility of being economical even in

*e-mail: pinatti@demar.faenquil.br

Trabalho apresentado no $1^{\circ}$ Congresso da Sociedade Brasileira em Materiais, Rio de Janeiro, Julho de 2002. the future 3 ; (2) BEM technologies process any kind of biomass (wood and its residues, sugarcane bagasse and trash, agricultural residues, grass, organic matter of municipal solid waste - MOL, organic sludge and petrochemical polymer residues such as tires and plastics); (3) the six basic technologies are a sequential cleaner of any potentially toxic elements (Ni, Cr, Cu, Cd, Zn, Pb, Hg, As, Se and Sb) and alkaline and alkaline-earth elements ( $\mathrm{K}, \mathrm{Na}, \mathrm{Ca}, \mathrm{Mg}$ ) present in the raw materials. They generate clean products along the horizontal axis and concentrate the impurities in the vertical axis into a final submicrometric, partially nanometric powder (SM/NM), which is finally stabilised in vitrified ceramic (grès-type or porcelain materials with $50 \mathrm{MPa}$ of flexural strength and $0.2 \%$ of water absorption). The horizontal axis (economical) and the vertical axis (ecological) represent the eco-eco concept. As water is completely recycled and CCTE produces clean gases the BR is an industrialisation process with null pollution because no solid, 
liquid or toxic gaseous emissions are discharged into the environment. In the future $\mathrm{CO}_{2}$ released from the CCTE will be collected into carbon molecular sieves $(\mathrm{CMS})^{4}$ and commercialised; (4) the main large-scale economical prod- ucts that compete with other sources of materials and energy are furfural (FF) and its derivatives including the ecological and most clean P-series fuel (50\% ethanol, 30\% > C5 hydrocarbons, $20 \%$ methyltetrahydrofuran $)^{5}$, cellulignin fuel

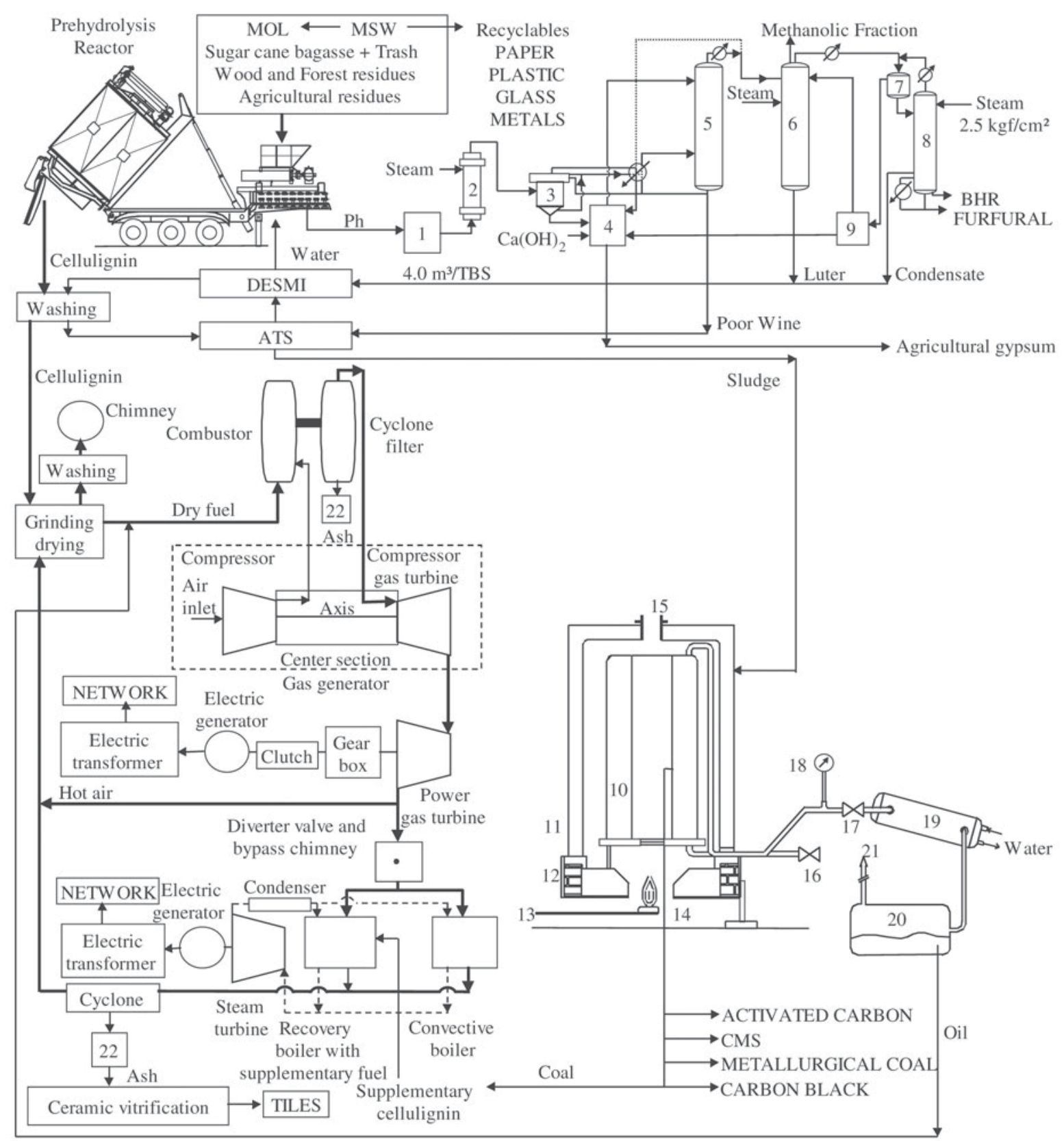

MSW - Municipal Solid Waste; MOL - Organic Matter of MSW; ATS - Affluent Treatment Station; DESMI - Demineraliser; BHR = Bottom Heavy Residue; CSM - Carbon Molecular Sieve; 1 - Prehydrolysate Storage Tank; 2 - Furfural Reactor; 3 - Flash Tank; 4 - Tank of Neutralisation and Press Filter; 5 - Preconcentration Column; 6 - Concentration Column; 7 - Decanter; 8 - Rectifier Column; 9 - Tank of Furfural Solution; 10 - Low Temperature Conversion Reactor; 11 - Furnace; 12 - Refractory Basis; 13 - LPG Inlet; 14 - Burner; 15 - Combustion Gases Exhaustion; 16 - Inert Gas Inlet; 17 - Reaction Gases Outlet; 18 - Pressure Gauge; 19 - Condenser; 20 - Condensable Gases Collector Tank; 21 - Non Condensable Gases Outlet; 22 - Ash to Ceramic Vitrification

Figure 1. Biomass Refinery basic technogies. 
(CL), oil (diesel, fatty and limonene-oil type), charcoal (fuel, metallurgical, activated and CMS), electric energy and the SM/NM powders. There are a large number of other products that will be made competitive in a near future.

The first BR will be installed in Lorena - SP, Brazil. It will process 300 ton of dry biomass (TDB)/day of MSW from seven cities around Lorena, rice husks, wood residues, tires and organic sludge (domestic and industrial).

\subsection{Basic Technologies and Products}

The first basic technology to be considered is the diluted acidic prehydrolysis of the biomass. The prehydrolysis reactor (Fig. 1) is made of steel lined with titanium and operates at $0.8 \mathrm{MPa}, 180{ }^{\circ} \mathrm{C}$ and $1.5 \% \mathrm{H}_{2} \mathrm{SO}_{4}{ }^{6}$. In the process the hemicellulose of the biomass is hydrolysed to a sugar solution (mainly xylose), called prehydrolysate, that is the raw material for the FF plant. The solid product of the prehydrolysis is the cellulignin (CL), a fuel free of $\mathrm{K}+\mathrm{Na}$ and with porosity at the macromolecular level (Fig. 2 - Table 1). The CL burns by its internal porosity without shrinkage of the particle diameter $(\phi<200 \mu \mathrm{m})$ avoiding sintering and resulting in a SM/NM particle ${ }^{7}$. The conventional burning occurs at the external particle surface with shrinkage and the high $\mathrm{K}+\mathrm{Na}$ contents always cause sintering of the particle. Some prehydrolysis reactors are stationary for MOL processing and some move to the production sites for wood and agricultural residues processing, avoiding the high transportation cost of raw material.

The second technology is the furfural production ${ }^{8,9}$. It consists of the dehydration of the prehydrolysate and distillations columns (Fig. 1). Besides the fact that furfural contributes to $25 \%$ of $\mathrm{BR}$ revenue it generates distilled water that, after demineralisation in a cationic resin column, is used for cellulignin washing aiming to lower the $\mathrm{Na}+\mathrm{K}$ contents into the parts per million level.

Next technology is the affluent/water treatment station (ATS/WTS) that consists of the neutraliser, decanter, cavitated air flotation with belt sludge press and demineralisation plant composed of sand/carbon filters and cationic column. This unit cleans the $\mathrm{K}+\mathrm{Na}+\mathrm{Ca}$ from the water to be recycled and resists organic contaminants. Anionic column does not resist organic contaminants and coincidentally it is not necessary in the BF. Water recycling without disposition to the environment avoids the need of biological treatments. The water comes from the biomass and leaves the refinery as steam in the CL dryer. The sludge goes to the low temperature conversion.

The low temperature conversion (LTC) reactor $^{10}$ (Fig. 1) has an annular furnace and a condensation unit. It is a hermetic catalytic process operating at $400{ }^{\circ} \mathrm{C}$ and produces distilled oil and coal. The LTC processes organic sludge, tires, and plastics. When the feeding material is clean the coal is used for domestic or siderurgical/metallurgical applications and when contaminated it is burned in a controlled way in the thermoelectric boiler. There is no sintering of the ash in the LTC process.

The main equipments of the combined cycle thermoelectric plant - CCTE - (Fig. 1) are the cellulignin dryer, external combustor, cyclone filter, gas turbine/generator set and recovery boiler/steam turbine. The recovery boiler is divided into two units: the first uses contaminated coal as a supplementary fuel and the second unit is just a convective boiler. The combustion in the recovery boiler occurs at less than $800{ }^{\circ} \mathrm{C}$; this avoids sintering of the ash and produces a $\mathrm{SM} / \mathrm{NM}$ powder. All the ashes produced by conventional processes have high $\mathrm{K}+\mathrm{Na}$ contents and they burn at temperatures higher than $800{ }^{\circ} \mathrm{C}$, which promotes the sintering of the particles in crystalline forms with size particle above the micrometric range.

The revenue of BR distributes into $25 \%$ from recyclable materials, $25 \%$ from furfural, $45 \%$ from electric energy and $5 \%$ from SM/NM ash.

\section{Experimental procedure}

The red clay used in the work is from the Lorena City and geologically belongs to the Taubaté Basin. Its main phases are: quartz ( $\mathrm{SiO}_{2}$-hexagonal); kaolinite $\left(\mathrm{Al}_{2}\left(\mathrm{Si}_{2} \mathrm{O}_{5}\right)(\mathrm{OH})_{4}\right.$ - triclinic); muscovite $\left(\mathrm{KAl}_{2}\left(\mathrm{Si}_{3} \mathrm{Al}\right) \mathrm{O}_{10}(\mathrm{OH})_{2}\right.$ - monoclinic $)$; and hematite $\left(\mathrm{Fe}_{2} \mathrm{O}_{3}\right.$ hexagonal). Muscovite $\left(\mathrm{KAl}_{2}\left(\mathrm{Si}_{3} \mathrm{Al}\right) \mathrm{O}_{10}(\mathrm{OH})_{2}\right)$ and illite $\left(\mathrm{K}_{\mathrm{x}}(\mathrm{AlMg})_{4}(\mathrm{SiAl})_{8} \mathrm{O}_{20}(\mathrm{OH})_{4} \cdot \mathrm{nH}_{2} \mathrm{O}\right)$ are different species, both dioctaedric of the mica group with a 2:1 layer structure. The qualitative phase identification in the clay, ashes

Table 1. Inorganic constituent concentrations of the Eucalyptus grandis wood and cellulignin produced from the wood (mg/g).

\begin{tabular}{lccccccccccc}
\hline Fuel & $\mathrm{Ca}$ & $\mathrm{K}$ & $\mathrm{Na}$ & $\mathrm{Mg}$ & $\mathrm{P}$ & $\mathrm{Al}$ & $\mathrm{Si}$ & $\mathrm{Mn}$ & $\mathrm{Fe}$ & $\mathrm{Zn}$ & $\mathrm{S}$ \\
\hline Eucalyptus grandis $^{a}$ & 510 & 630 & 100 & 260 & 120 & 240 & 140 & 25 & 40 & 10 & 180 \\
Washed Cellulignin - PW $^{b, c}$ & 55 & 40 & 45 & 20 & $<15$ & 130 & 160 & 2 & 15 & 10 & 80 \\
Non Washed Cellulignin - DW $a, d$ & 120 & 35 & 55 & 30 & $<15$ & 220 & 120 & 1 & 15 & 8 & 200 \\
Washed Cellulignin - DW $^{a, d}$ & $<53$ & $<5$ & $<1$ & $<60$ & $<2$ & $<40$ & $<120$ & $<2$ & $<7$ & $<4$ & $<80$ \\
\hline
\end{tabular}

${ }^{a}$ Quantitative analysis by inductively coupled plasma optical emission spectrometry; ${ }^{b}$ Prehydrolysis processed with potable water;

${ }^{c}$ Semi-quantitative analysis by X-ray fluorescence; ${ }^{d}$ Prehydrolysis processed with deionized water 


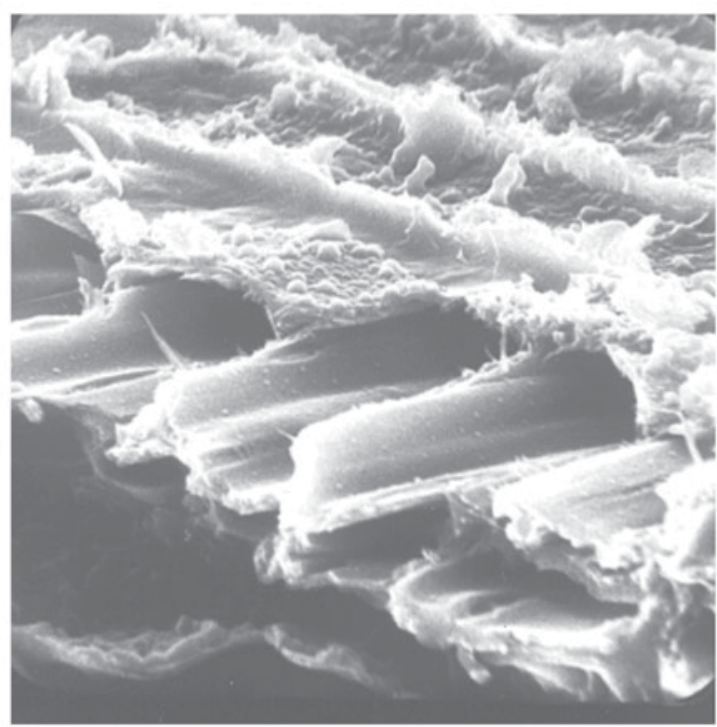

(a)

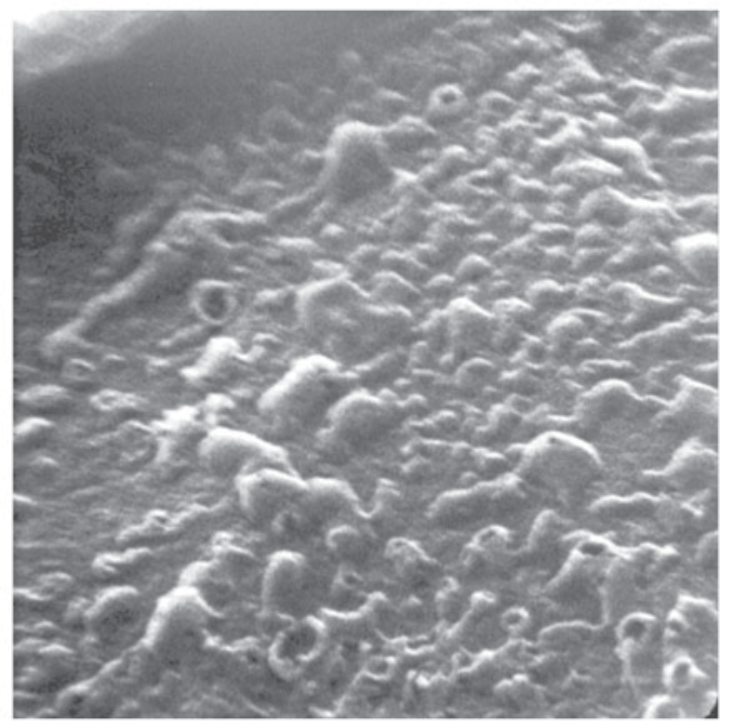

(c)

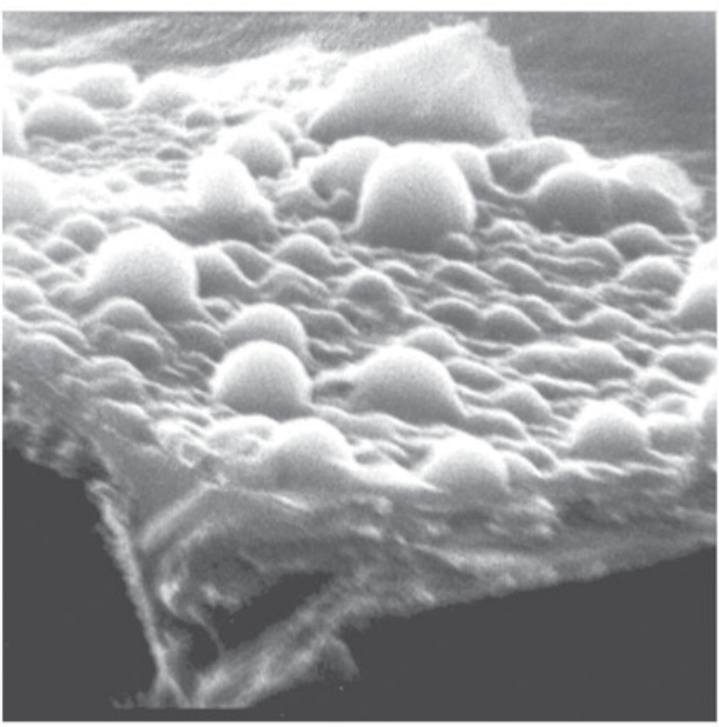

(b)

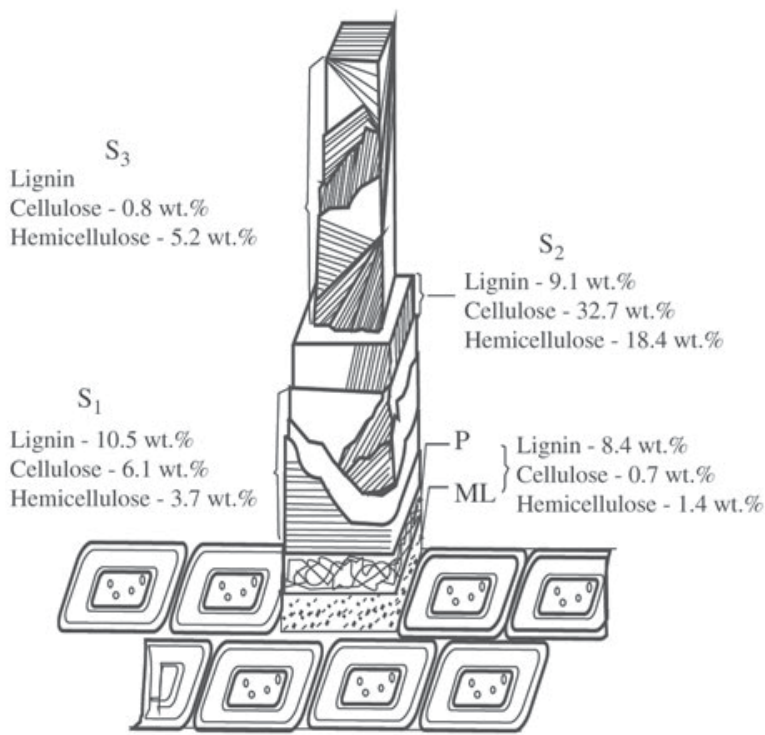

(d)

Figure 2. Microstructure of the catalytic cellulignin. a) Fragile fracture of the cellulose; b) lignin globulization of cellular medium lamella; c) microvolcanoes at the internal wall of the cytoplasm; d) structure of the cellular wall.

and ceramic materials was performed by X-ray diffraction. This technique was also applied to identify the transition from the crystalline to the amorphous (glass) state in the ashes as a function of the sintering temperature ${ }^{11}$.

Presently the powders produced by the Biomass Refinery are: (1) ash of the organic matter of the municipal solid waste, obtained by the direct burning of the MOL at $700{ }^{\circ} \mathrm{C}$. It is denominated 100\% MOL ash; (2) ash of the burning of the cellulignin obtained by the prehydrolysis of a $100 \%$ wood, with and without bark (denominated 100\% wood CL ash), processed with potable and deionised water; (3) ash of the burning of the cellulignin obtained by the prehydrolysis of $50 \%$ MOL $150 \%$ wood, processed with potable and deionised water (denominated by (CL)* ash); (4) ash of the rice husk (silica), and (5) recovered carbon black obtained by the LTC of tires.

The microstructures of ceramic materials were characterised by scanning electron microscopy (SEM), using the LEO $1450 \mathrm{VP}$ at DEMAR. Due to the SM/NM particle size nature of the ashes a high-resolution scanning electron mi- 
croscope was also used (SEM - FEG Jeol JSM-6330F) at the LME/LNLS, Campinas - SP, Brazil.

The pressing behaviour of the particles was observed through the compaction curves of the powders. A single action piston pressing was used .

The preparation of the ceramic mixtures followed a typical procedure: the clay was disaggregated in a ball mill and classified in a $130 \mu \mathrm{m}$ (100 mesh) sieve. The ashes were also desagglomerated in ball mills and classified in a $75 \mu \mathrm{m}$ (200 mesh) sieve. Feldspar was used as received. Clay, ash and feldspar were mixed in a ball mill for one hour, wetted at $8 \%$ humidity, passed through a $425 \mu \mathrm{m}$ ( 35 mesh) sieve, compacted at $18 \mathrm{MPa}$ and dried at $110^{\circ} \mathrm{C}$ for $24 \mathrm{~h}$. Samples of $\sigma_{\max }=54 \mathrm{MPa}$ were obtained indicating that the ceramic mixture preparation was adequate. The samples have di- mensions of $114 \mathrm{~mm}$ in length, $25.4 \mathrm{~mm}$ in width and $6 \mathrm{~mm}$ in thickness. All samples were sintered at $1200{ }^{\circ} \mathrm{C}$; pure clay was also sintered at $11500^{\circ} \mathrm{C}^{12}$.

Weibull distribution ( 23 specimens) was applied to the rupture strength values (3-point flexural test) to investigate the mechanical behaviour of the ceramic materials.

Chemical analyses of the main constituents of the raw and ceramic materials were made by inductively coupled plasma optical emission spectrometry (ICP-OES) (Table 2). Solubilization and leaching tests (Brazilian Standards Series 10000) were applied to the $100 \% \mathrm{MOL}$ ash, (CL)* ash and to the ceramic materials obtained with the ash additions in order to verify the mobility of pollutant metals. The potentially toxic metals $(\mathrm{Ag}, \mathrm{Al}, \mathrm{Ba}, \mathrm{Cd}, \mathrm{Cr}, \mathrm{Cu}, \mathrm{Fe}, \mathrm{Mn}$, $\mathrm{Na}, \mathrm{Pb}$ and $\mathrm{Zn}$ ) determination in the solubilization and leach-

Table 2. Chemical composition of the raw materials and ceramic mixtures.

\begin{tabular}{|c|c|c|c|c|c|c|c|c|c|}
\hline \multirow{3}{*}{$\begin{array}{l}\text { Composition } \\
(\%)\end{array}$} & \multicolumn{9}{|c|}{ Raw Materials $^{a}$} \\
\hline & \multicolumn{3}{|c|}{ Clay } & \multirow{2}{*}{ MOL ash } & \multirow{2}{*}{$(\mathrm{CL})^{* b}$} & \multicolumn{4}{|c|}{ Feldspar $^{c}$} \\
\hline & \multicolumn{2}{|c|}{ Forte Dura } & Forte & & & & $\mathrm{F} 1$ & & F2 \\
\hline $\mathrm{Al}_{2} \mathrm{O}_{3}$ & \multicolumn{2}{|c|}{31.6} & 22.6 & 8.4 & 6.2 & \multicolumn{2}{|r|}{25.8} & \multicolumn{2}{|r|}{19.0} \\
\hline $\mathrm{CaO}$ & \multicolumn{2}{|c|}{0.2} & 0.1 & 10.6 & $\sim 10.8$ & \multicolumn{2}{|r|}{0.1} & \multicolumn{2}{|r|}{0.03} \\
\hline $\mathrm{Fe}_{2} \mathrm{O}_{3}$ & \multicolumn{2}{|c|}{4.1} & 4.8 & 2.9 & 1.9 & \multicolumn{2}{|r|}{0.1} & \multicolumn{2}{|r|}{0.03} \\
\hline $\mathrm{K}_{2} \mathrm{O}$ & \multicolumn{2}{|c|}{1.7} & 2.0 & 9,0 & 2.2 & \multicolumn{2}{|r|}{11.3} & \multicolumn{2}{|r|}{12.0} \\
\hline $\mathrm{MgO}$ & \multicolumn{2}{|c|}{0.4} & 0.4 & 1.8 & $-^{d}$ & & 0.6 & & 0.001 \\
\hline $\mathrm{Na}_{2} \mathrm{O}$ & & & - & 6.3 & 1.4 & & 0.4 & & 3.2 \\
\hline $\mathrm{Nb}_{2} \mathrm{O}$ & & & 0.2 & - & - & & - & & - \\
\hline $\mathrm{SiO}_{2}^{2}$ & & & 69.1 & 39.3 & 54.8 & & 51.7 & & 65.5 \\
\hline $\mathrm{TiO}_{2}^{2}$ & & & 0.8 & - & - & & 1.4 & & - \\
\hline Loss on ignition & & & - & 18.8 & - & & 11.2 & & - \\
\hline Total & & & 100 & 97.1 & - & & 92.8 & & 99.8 \\
\hline Composition & & & & & xtures ${ }^{a}$ & & & & \\
\hline$(\%)$ & $\mathrm{PC}^{e}$ & $\begin{array}{c}\text { Clay }+ \\
\text { MOL } \\
\operatorname{ash}^{f} \\
\end{array}$ & $\begin{array}{c}\text { Clay }+ \\
40 \%(\mathrm{CL})^{*} \\
\text { Ash }^{g} \\
\end{array}$ & $\begin{array}{c}\text { Clay + } \\
54 \%(\mathrm{CL})^{*} \\
\text { ash }^{h}\end{array}$ & $\begin{array}{c}\text { Clay }+20 \% \mathrm{~F} \\
+20 \%(\mathrm{CL})^{*} \\
\operatorname{ash}^{i}\end{array}$ & & $\mathrm{PC}+$ & $\% \mathrm{~F}^{j}$ & \\
\hline & & & & & & 10 & 20 & 30 & 40 \\
\hline $\mathrm{Al}_{2} \mathrm{O}_{3}$ & 27.1 & 24.6 & 19.0 & 16.2 & 21.4 & 27.0 & 26.8 & 26.7 & 26.6 \\
\hline $\mathrm{CaO}$ & 0.1 & 1.6 & 4.8 & 6.4 & 2.5 & 0.15 & 0.14 & 0.13 & 0.13 \\
\hline $\mathrm{Fe}_{2} \mathrm{O}_{3}$ & 4.5 & 4.3 & 3.4 & 3.0 & 3.0 & 4.8 & 5.2 & 5.5 & 5.8 \\
\hline $\mathrm{K}_{2} \mathrm{O}^{3}$ & 1.9 & 2.8 & 2.0 & 2.1 & 4.0 & 2.8 & 3.7 & 4.7 & 5.6 \\
\hline $\mathrm{MgO}$ & 0.4 & 0.6 & 0.4 & 0.5 & 0.3 & 0.4 & 0.44 & 0.46 & 0.50 \\
\hline $\mathrm{Na}_{2} \mathrm{O}$ & $-^{d}$ & 0.9 & 0.6 & 0.8 & 0.9 & 0.04 & 0.08 & 0.12 & 0.16 \\
\hline $\mathrm{Nb}_{2} \mathrm{O}_{5}$ & 0.1 & 0.1 & 0.1 & 0.05 & 0.1 & 0.14 & 0.12 & 0.1 & 0.09 \\
\hline $\mathrm{SiO}_{2}{ }^{2}$ & 65.0 & 61.5 & 58.8 & 56.6 & 62.0 & 63.7 & 62.3 & 61.0 & 59.7 \\
\hline $\mathrm{TiO}_{2}^{2}$ & 1.0 & 0.9 & 0.8 & 0.8 & 0.7 & 1.0 & 1.1 & 1.1 & 1.2 \\
\hline Outros & & & 4.3 & 5.7 & 2.2 & & & & \\
\hline Total & 100 & 97.3 & 94.2 & 92.2 & 97.0 & 100 & 99.9 & 99.8 & 99.8 \\
\hline
\end{tabular}

${ }^{a}$ Analysis by inductively coupled plasma optical emission spectrometry (ICP-OES); ${ }^{b}$ Semi-quantitative analysis; ${ }^{c}$ Supplier data; ${ }^{d}$ - Not determined; ${ }^{e}$ Sintered clay without any addition; ${ }^{f} \mathrm{Clay}+13.5 \%$ MOL ash; ${ }^{g} \mathrm{Clay}+40 \%(\mathrm{CL}) *$ ash; ${ }^{h} \mathrm{Clay}+54 \%(\mathrm{CL}) *$ ash; ${ }^{i} \mathrm{Clay}+$ $20 \%$ feldspar $+20 \%(\mathrm{CL}) *$ ash; ${ }^{j}$ Clay + feldspar. 
ing extracts of some ashes and ceramic materials prepared with ash additions was also carried out by ICP-OES.

\section{Results and discussion}

The microstructures of the powders (Figs. 3a-3f) presented the following characteristics: $100 \%$ MOL ash shows elementary particle sizes less than $100 \mathrm{~nm}$ and agglomerates greater than $2 \mu \mathrm{m}$ (Fig. 3a). Particle distribution measurements (sedimentation technique with laser Horiba model CAPA-700) shows agglomerate diameters of $(6.27 \pm 9.22) \mu \mathrm{m}$. Ash of (CL)* washed with deionised water shows a fraction of the particles with $1 \mu \mathrm{m}$ in size (due to the clay contamination in the MOL), and a fraction with particles of $100 \mathrm{~nm}$ in size (due to the biomass ash) (Fig. 3b). Particle distribution measurements show agglomerate diameter size of $(4.80 \pm 7.94) \mu \mathrm{m}$. Ash of $100 \%$ wood washed with deionised water shows elementary particle sizes less than $100 \mathrm{~nm}$ and agglomerates greater than $2 \mu \mathrm{m}$ (Fig. 3c). Silica of rice husk cellulignin washed with potable water and burned at $700{ }^{\circ} \mathrm{C}$ shows elementary particle size of $100 \mathrm{~nm}$ and agglomerates greater than $2 \mu \mathrm{m}$ (Fig. 3d). Recovered carbon black from low temperature conversion of tires at $420{ }^{\circ} \mathrm{C}$, heated at $800{ }^{\circ} \mathrm{C}$ for $30 \mathrm{~min}$ and desagglomerated by attrition milling shows elementary particle size of $60 \mathrm{~nm}$ (Fig. 3e) similar to the commercial carbon black CCB N339 (Fig. 3f). The specification of particle size of the commercial carbon black is $30 \mathrm{~nm}$. SEM measurements of the commercial powder indicate that the elementary particle size is higher than the actual size, that is, the resolution of the scanning microscope has reached its limit.

The compaction curves (Figs. $4 a-4 b$ ) showed the following characteristics: (1) the presence of the three stages of compaction (flux and rearrangement, deformation and densification of the agglomerates); (2) very low apparent specific mass (ASM) in the first stage; (3) in the transition from the second to the third stage (pressures $\approx 200 \mathrm{MPa}$ ) the ASM has typical values $\left(>1800 \mathrm{~kg} / \mathrm{m}^{3}\right)$ for the ashes but low values for the silica and RCB $\left(<1200 \mathrm{~kg} / \mathrm{m}^{3}\right)$. CCB N 339 has lower value than $\mathrm{RCB}$, indicating the possibility of improvements in the process. The low values of ASM are corroborated by the sample electrical charging in the SEM measurements, even with a gold coating of $20 \mathrm{~nm}$ in thickness, which can be attributed to a polarisation of those powders.

Cellulignin is a catalytic fuel to be burned in gas turbines. The definition of the maximum working temperature of the turbine determines the power to be achieved. On the other hand, working temperature must be such that ash deposits in the vanes and blades are avoided. The use of normalised integrated intensity of X-ray diffraction peaks as a function of the sintering temperature of the ashes allows the definition of the transition temperature from the crystalline to the glassy phase. The data of Fig. 5 show that all samples bump up at the following temperatures: $100 \% \mathrm{MOL}$ - $650{ }^{\circ} \mathrm{C}$; (CL)* ash washed with deionised water $-750{ }^{\circ} \mathrm{C}$; ash of $100 \%$ wood CL with bark washed with deionised water $-800{ }^{\circ} \mathrm{C}$. The technique has proved to be very effective for the definition of the maximum working temperature of a gas turbine burning cellulignin in an external combustor without generating ash deposits in the vanes and blades. It is possible to work at $750{ }^{\circ} \mathrm{C}$ when the MOL is present (5.5 MW power in the GE/LM 1500 gas turbine) and at $788{ }^{\circ} \mathrm{C}$ with pure wood cellulignin (9.5 MW in the same turbine) $)^{13,14}$.

The constituents of the ash in the biomass can be classified in four groups ${ }^{15}$ : refractory materials $(\mathrm{Si}, \mathrm{Ti}, \mathrm{Al})$, alkaline and alkaline-earth materials ( $\mathrm{K}, \mathrm{Na}, \mathrm{Ca}, \mathrm{Mg}$ ), non-metallic materials $(\mathrm{Cl}, \mathrm{S}, \mathrm{P})$ and iron $(\mathrm{Fe})$. Thermogravimetric (TG) and differential thermal analysis (DTA) were carried out for three types of ashes (Fig. 6a-6b). The results do not correlate with the composition of the ash deposits (sintered or melted) because their constituents occur in various forms of dissolved salts, cations attached to carboxylic and other functional groups, complex ions, chemisorbed materials, oxides, silicates and sulphides. Based on the TG data the final mass loss of the $100 \%$ MOL ash is $30 \%$ and the others are around $10 \%$. The difference is due to the losses in the prehydrolysis process. Although DTA data are quite confusing it is possible to identify some peaks: liberation of liquid and adsorbed water at $85{ }^{\circ} \mathrm{C}$, liberation of cation coordinated water at $\approx 300{ }^{\circ} \mathrm{C}$ (end of positive slop in the DTA curve), liberation of constitutional water at $\approx 500{ }^{\circ} \mathrm{C}$, eutectic transformation present in the $\mathrm{SiO}_{2}-\mathrm{K}_{2} \mathrm{O}$ phase diagram at $\approx 760{ }^{\circ} \mathrm{C}$; melting or decomposition of $\mathrm{CaCO}_{3}$ $\left(1339{ }^{\circ} \mathrm{C}\right), \mathrm{CaSO}_{4}\left(750-950{ }^{\circ} \mathrm{C}\right.$ in the presence of silicates $)$, $\mathrm{MgSO}_{4}\left(1124{ }^{\circ} \mathrm{C}\right.$ - decomposition), melting of $\mathrm{FeS}_{2}$ $\left(1171^{\circ} \mathrm{C}\right.$ ) explaining the decrease of all curves between 950 and $1150{ }^{\circ} \mathrm{C}$. The exothermic peak around $1150{ }^{\circ} \mathrm{C}$ is not well understood but it indicates that some carbon is being burned. In this paper DTA data above $1200{ }^{\circ} \mathrm{C}$ will not be analysed. Comparing the data of the Fig. 5 and Fig. 6 it is clear that the integrated intensity of the X-ray diffraction peaks technique developed in this work correlates better with the temperature of the ash deposits in the boiler and gas turbine than TG/DTA data, as stated in the literature ${ }^{15}$.

\subsection{Mechanical behaviour of the vitrified ceramics}

The $100 \%$ MOL ash, the (CL)* ash and feldspar were added to a kaolinitic/muscovite red clay available in the Taubaté Basin of the Paraíba Valley - SP, Brazil. The objective was to prepare ceramic plates for pavement, which requires less dimensional control. Wall tiles specifications can be reached with other clays (smaller linear retraction and loss on ignition). Table 2 gives the composition of the clay, the ashes, the feldspar and the composition of the ceramic mixtures as well. 


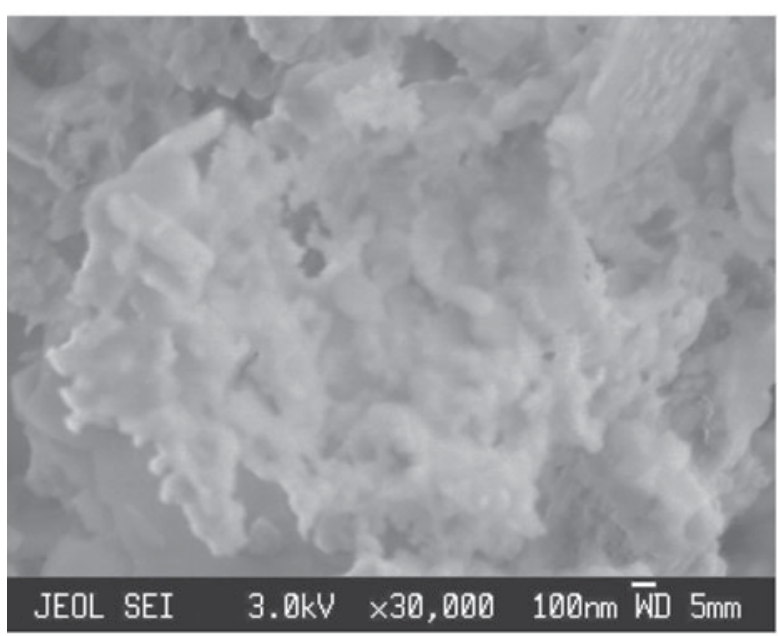

(a)

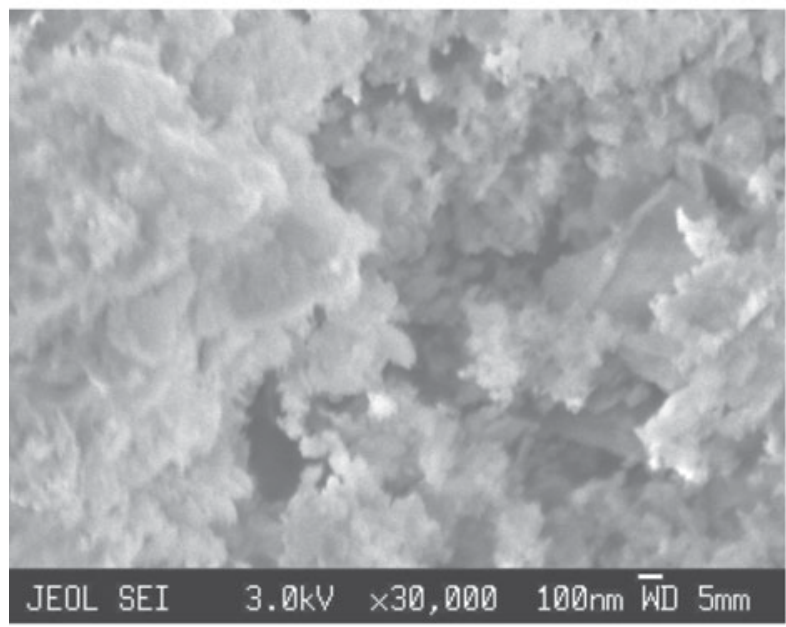

(c)

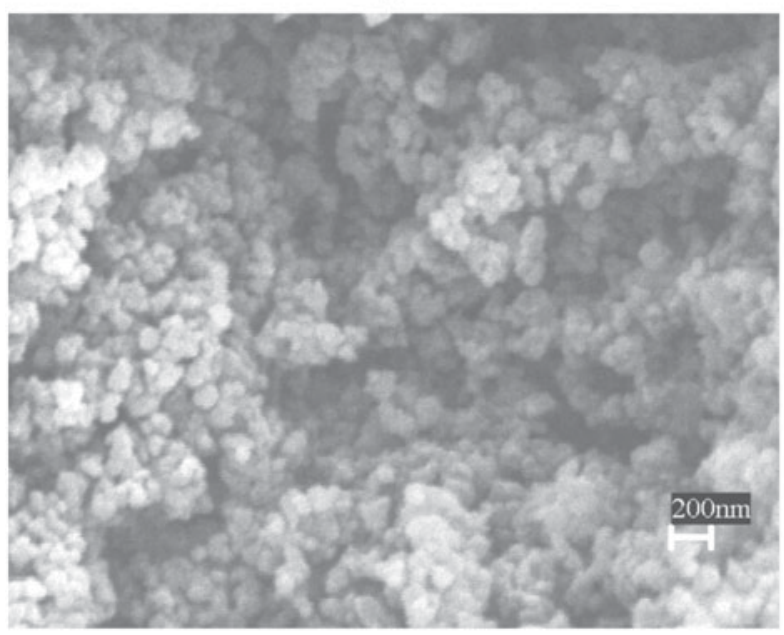

(e)

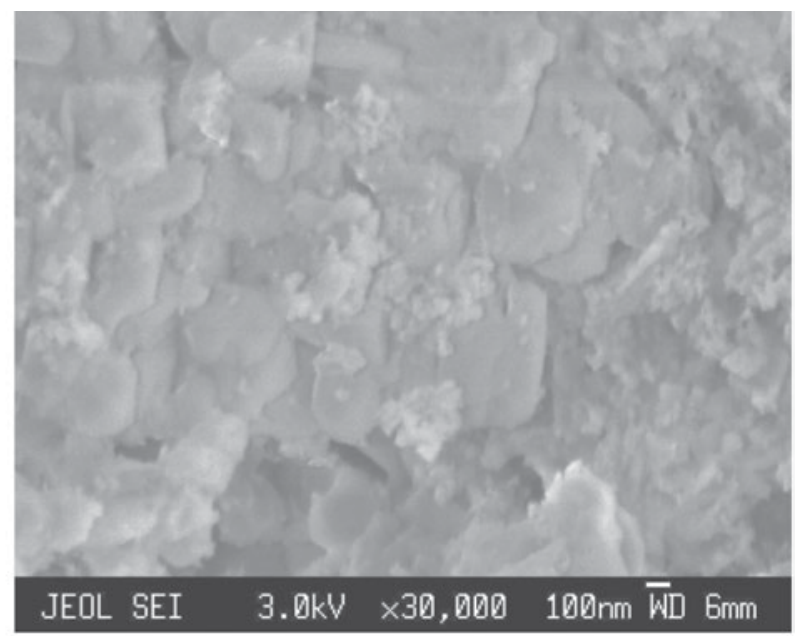

(b)

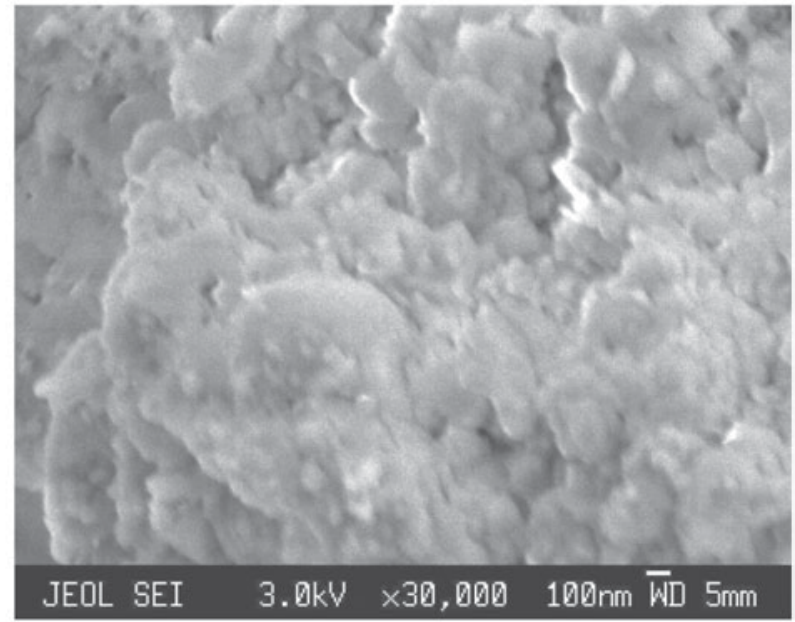

(d)

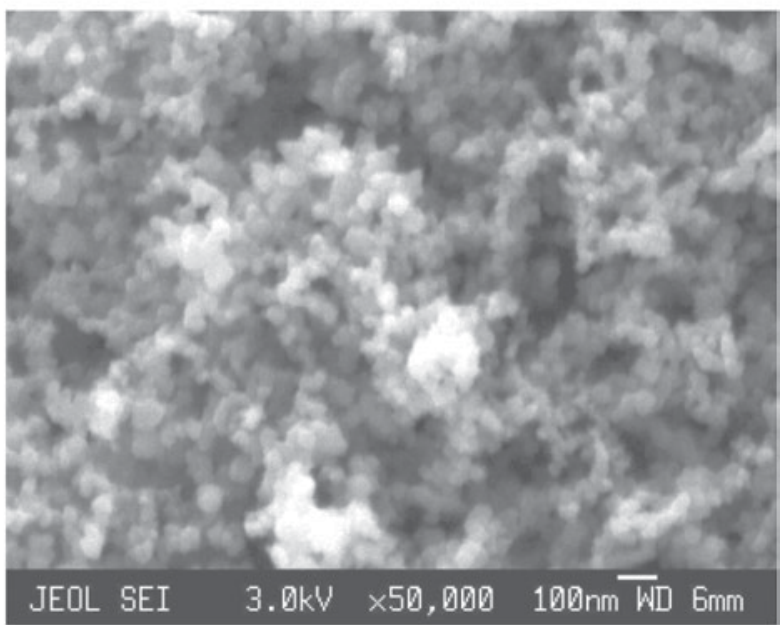

(f)

Figure 3. Microstructures of some powders produced by the Biomass Refinery: a) 100\% MOL ash; b) (CL)* ash washed with deionised water; c) $100 \%$ wood with bark CL ash washed with deionised water; d) Silica of rice husk CL washed with potable water and burned at $700{ }^{\circ} \mathrm{C}$; e) Recovered carbon black from tires by LTC, $420{ }^{\circ} \mathrm{C}$, heated at $800{ }^{\circ} \mathrm{C}$ for 30 min and desagglomerated by attrition mill; f) Commercial carbon black N339. 


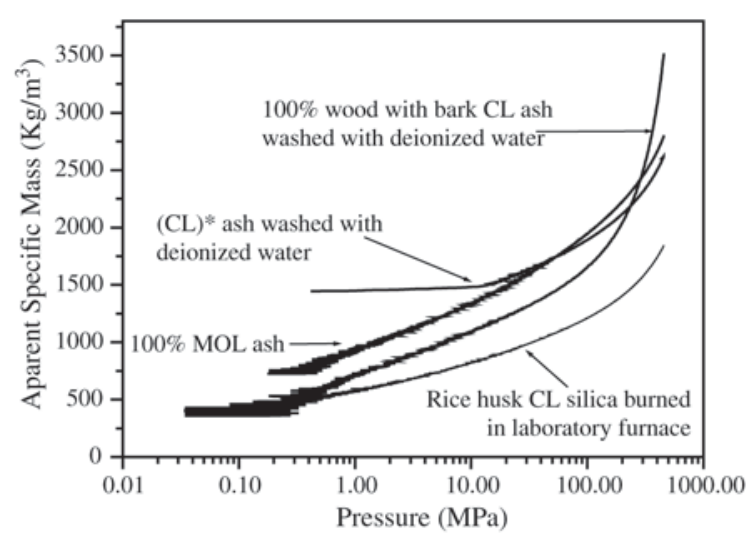

(a)

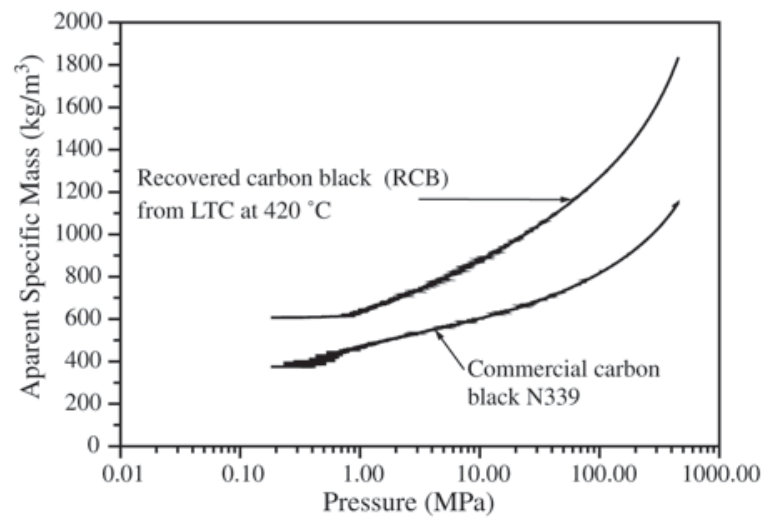

(b)

Figure 4. Compaction curves for some powders produced by the Biomass Refinery: a) Compaction curves of ashes and silica; b) Compaction curves of recovered and commercial N339 carbon black.

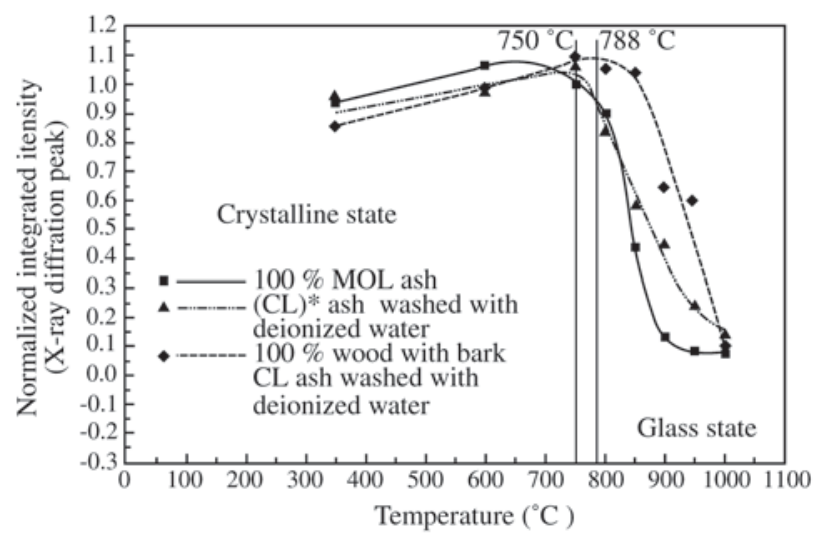

Figure 5. Normalised integrated intensity of X-ray diffraction peaks as a function of the sintering temperature of some ashes.

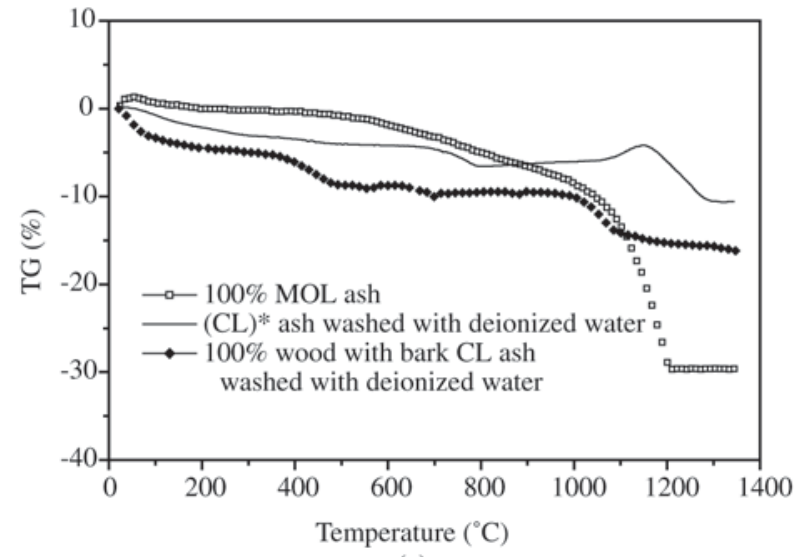

(a)

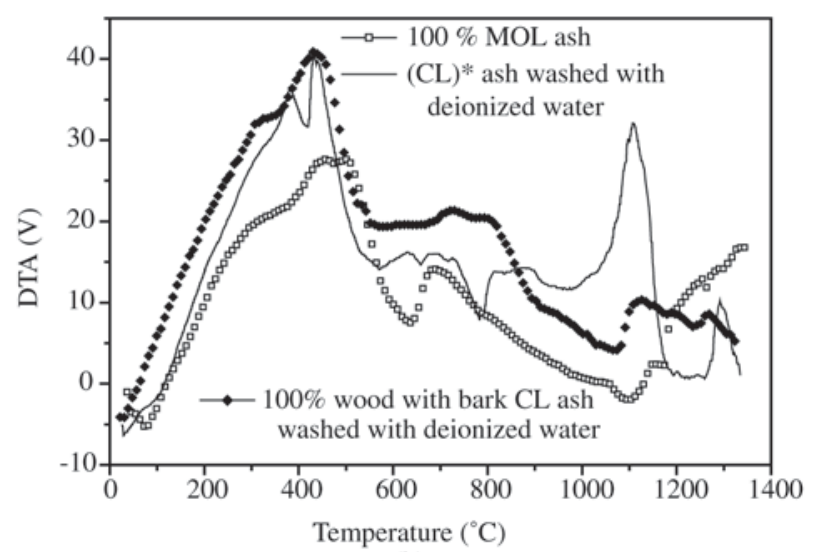

(b)

Figure 6. a) Thermo-gravimetric analysis of some ashes; b) Differential thermal analysis of some ashes.

A concept of an "equivalent composition" is introduced for the vitrified ceramics. It means to group the inorganic constituents according to their behaviour in the ceramic phase diagram. The refractory constituents $\left(\mathrm{Al}_{2} \mathrm{O}_{3}\right.$ and $\left.\mathrm{TiO}_{2}\right)$ are grouped under the designation of $\Sigma\left(\mathrm{Al}_{2} \mathrm{O}_{3}\right)_{\mathrm{eq}}$. Iron oxide is grouped with silica due to its intermediate melting point, between the refractories and fluxes, giving the $\Sigma\left(\mathrm{SiO}_{2}\right)_{\text {eq }}$. The fluxes $\mathrm{Na}_{2} \mathrm{O}, \mathrm{K}_{2} \mathrm{O}, \mathrm{CaO}$ and $\mathrm{MgO}$ are put together under the designation of $\Sigma\left(\mathrm{K}_{2} \mathrm{O}\right)_{\mathrm{eq}}$. Figure 7 shows the "equivalent composition" phase diagram where some ceramics and some points of the silica/leucite/mullite phase diagram are indicated (P1 to $\mathrm{P} 4)^{16}$. The addition of the feldspar (F1 batch - $\bullet$ ) in the pure clay $(\mathrm{PC}-\odot)$ situates the materials $(\mathrm{O})$ on the PC-F1 with constant $\Sigma\left(\mathrm{Al}_{2} \mathrm{O}_{3}\right)_{\mathrm{eq}}$. A second batch of feldspar (F2 batch) was only used to prepare the mixture clay $+20 \% \mathrm{~F}+20 \%(\mathrm{CL}) *$ ash. The addition of the $(\mathrm{CL})^{*}$ ash originates materials on the $\mathrm{PC}-(\mathrm{CL})^{*}$ 
line (+) in a direction of lower $\Sigma\left(\mathrm{Al}_{2} \mathrm{O}_{3}\right)_{\mathrm{eq}}$ content and higher $\Sigma\left(\mathrm{SiO}_{2}\right)_{\mathrm{eq}}$ and $\Sigma\left(\mathrm{K}_{2} \mathrm{O}\right)_{\mathrm{eq}}$ contents. The materials clay $+13.5 \%$ MOL ash ( $\mathbf{\Delta})$, clay $+20 \% \mathrm{~F}+20 \%(\mathrm{CL}) *$ ash $(\boldsymbol{\square})$ and clay $+\mathrm{Y} \%(\mathrm{CL}) *$ ash $(+)(\mathrm{Y}=20,30,40$, and $54 \%)$ are along the $\mathrm{PC}-(\mathrm{CL}) *$ line. Materials with proximate compositions have completely different properties. This fact may indicate that the nanometric fraction of the ash has a significant effect on the microstructures and properties of the ceramics.
Figure 8 shows the rupture stress as a function of $\Sigma\left(\mathrm{K}_{2} \mathrm{O}\right)_{\text {eq }}$ where it is indicated the Weibull distribution parameters $\sigma_{\mathrm{o}}$ and $\mathrm{m}$, the water absorption and the linear retraction values for some vitrified ceramics prepared according to the compositions given in Table 2 .

At the present stage of development the following points can be mentioned:

(1) The addition of feldspar in the $\mathrm{PC}\left(\sigma_{\mathrm{o}}=36 \mathrm{MPa}\right)$ has firstly decreased the rupture stress to $28 \mathrm{MPa}$ and then has

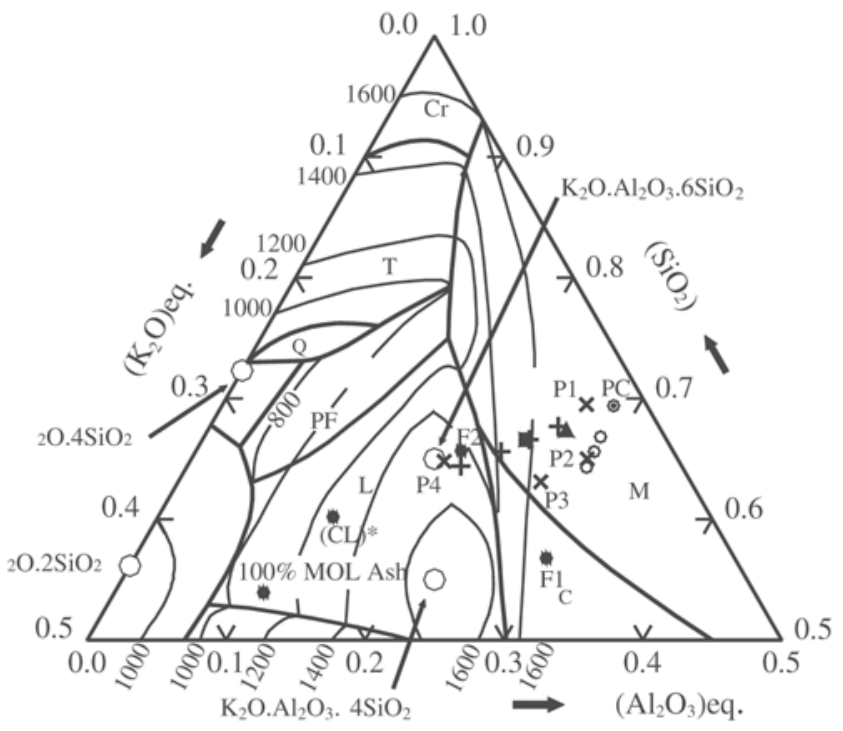

\begin{tabular}{|c|c|c|c|c|}
\hline $\begin{array}{l}\text { LEGEND } \\
\text { Raw Material }\end{array}$ & 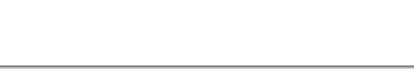 & $\left(\mathrm{Al}_{2} \mathrm{O}_{3}\right)$ eq. & $\left(\mathrm{K}_{2} \mathrm{O}\right)$ eq. & $\left(\mathrm{SiO}_{2}\right)$ eq. \\
\hline$\odot$ Pure Clay (PC) & & 28.2 & 2.4 & 69.4 \\
\hline $100 \%$ MOL Ash & & 10.7 & 35.3 & 53.9 \\
\hline$(\mathrm{CL})^{*}=(50 \% \mathrm{M}$ & OL $+50 \%$ Wood) CL ash & 12.6 & 27.2 & 60.2 \\
\hline - Feldspar (F1) batc & ch (a) & 29.7 & 13.6 & 56.7 \\
\hline$(\mathrm{F} 2)$ batc & ch (b) & 19.1 & 15.2 & 65.7 \\
\hline $\mathrm{O}$ Clay $+\mathrm{X} \% \mathrm{~F}$ & $X=20 \%$ & 28.5 & 4.6 & 66.8 \\
\hline & $X=30 \%$ & 28.7 & 5.7 & 65.6 \\
\hline & $X=40 \%$ & 28.8 & 6.9 & 64.3 \\
\hline $\mathbf{A}$ Clay $+13,5 \% \mathrm{MC}$ & OL Ash & 25.9 & 6.9 & 67.3 \\
\hline Clay $+20 \% \mathrm{~F}+2$ & $20 \%(\mathrm{CL}) *$ & 23.3 & 10.1 & 66.6 \\
\hline+ Clay + Y\% (CL) & $\mathrm{Y}=20 \%$ & 25.0 & 7.2 & 67.6 \\
\hline & $\mathrm{Y}=30 \%$ & 23.6 & 9.9 & 66.6 \\
\hline & $\mathrm{Y}=40 \%$ & 22.0 & 12.4 & 65.6 \\
\hline & $\mathrm{Y}=54 \%$ & 19.7 & 15.9 & 64.4 \\
\hline $\begin{array}{l}\times \text { Points in the } \\
\text { Silica/Leucite }\end{array}$ & $\begin{array}{l}\text { P1 Hard porcelain, semivitreous } \\
\text { whiteware }\end{array}$ & 26.2 & 4.3 & 69.5 \\
\hline and Mullite & P2 Vitreous tile, electrical insulators & 28.5 & 6.5 & 65.0 \\
\hline Phase Diagram & P3 Parian porcelain & 26.1 & 10.8 & 63.1 \\
\hline & P4 Dental porcelain & 18.3 & 16.9 & 64.8 \\
\hline
\end{tabular}

Ceramic Phase: M - Mullite; C - Corundum; L - Leucite; PF - Potash Feldspat; T - Tridymite; $\mathrm{Cr}$ - Cristobalite and Q - Quartz

(a)-Used in all samples except Clay $+20 \% \mathrm{~F}+20 \%(\mathrm{CL})^{*}$

(b)-Used only in Clay $+20 \% \mathrm{~F}+20 \%(\mathrm{CL})^{*}$

Figure 7. Equivalent composition for some ceramics and some points of the $\Sigma\left(\mathrm{SiO}_{2}\right)_{\mathrm{eq}}$ corner of the $\Sigma\left(\mathrm{SiO}_{2}\right)_{\mathrm{eq}} / \Sigma\left(\mathrm{K}_{2} \mathrm{O}\right)_{\mathrm{eq}} / \Sigma\left(\mathrm{Al}_{2} \mathrm{O}_{3}\right)_{\mathrm{eq}}$ phase diagram. 


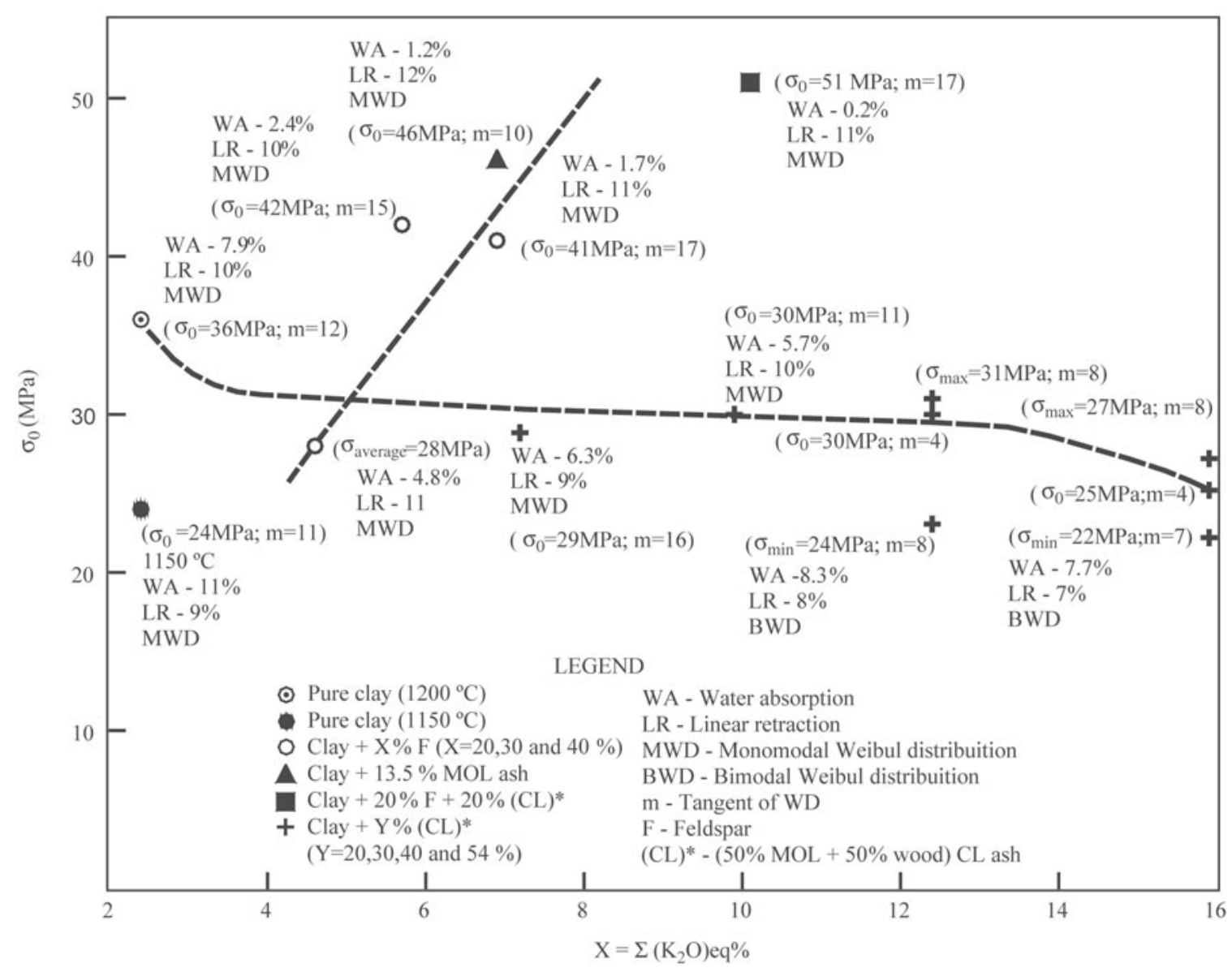

Figure 8. Weibull distribution parameters $\left(\sigma_{0}, \mathrm{~m}\right)$, water absorption and linear retraction as a function of $\Sigma\left(\mathrm{K}_{2} \mathrm{O}\right)_{\text {eq }}$ for some vitrified ceramics.

increased it to a $40 \mathrm{MPa}$ level for $40 \% \mathrm{~F}$ addition. The addition of the $(\mathrm{CL}) *$ ash has decreased $\sigma_{\mathrm{o}}$ to the $30 \mathrm{MPa}$ range and showed a bimodal Weibull distribution for $(\mathrm{CL})^{*}$ ash $>40 \%\left(\Sigma\left(\mathrm{K}_{2} \mathrm{O}\right)_{\text {eq }}>7.5 \%\right)$ probably due to a double region of phases, similar to the double phase behaviour in $\mathrm{Si}_{3} \mathrm{~N}_{4}{ }^{17}$. This agrees with the location of the clay $+40 \%(\mathrm{CL}) *$ and clay $+54 \%(\mathrm{CL}) *$ materials near the boundary of the mullite/ corundum/leucite phases, and may explain the not well understood behaviour of the decreasing of the ceramic strength with the addition of conventional ashes and residues ${ }^{18-20}$. The addition of $13.5 \% \mathrm{MOL}$ ash results in $\sigma_{\mathrm{o}}=46 \mathrm{MPa}$, water absorption $=1.2 \%$ and $\mathrm{m}=14$. Although very attractive as an additive MOL ash is an expensive material because it comes from the direct burning of the MOL without generating any furfural or electric energy. Industrially the ash from the controlled burning of the LTC coal obtained from the sludge will replace the MOL ash. This ash contains most of the $\mathrm{Na}_{2} \mathrm{O}+\mathrm{K}_{2} \mathrm{O}+\mathrm{CaO}$ digested in the prehydrolysis plant. The materials prepared with $20 \%(\mathrm{CL}) *$ ash $+20 \% \mathrm{~F}$ resulted in a porcelain ceramic $\left(\sigma_{\mathrm{o}}=51 \mathrm{MPa}\right.$, $\mathrm{m}=14$, water absorption $\left.=0.2 \%, \Sigma\left(\mathrm{K}_{2} \mathrm{O}\right)_{\mathrm{eq}}=7.6 \%\right)$. The explanation for such good results may come from two reasons: (a) in general, clays and feldspar consist of mineral particles with diameters above micrometric size. The vitrification homogeneity at the microscopic level depends on the liquid sintering mechanism hindered by the very high viscosity and (b) (CL)* and MOL ashes are SM/NM particles known to have lower melting point than micrometric particles, thus originating a fraction of liquid with lower viscosity and higher mobility. The overall result is a better homo-geneisation.

(2) Application of the Griffith criteria of fracture mechanics to the red clay states that $\mathrm{K}_{\mathrm{lc}}=1.12 \sigma(\pi \mathrm{c})^{1 / 2}$ where $\mathrm{K}_{1 \mathrm{c}}=0.59 \mathrm{MPa} \cdot \mathrm{m}^{1 / 2}{ }^{21}$. Based on the results of the Weibull distribution of the rupture stress, the critical fault length was calculated for four ceramics: clay $+13.5 \%$ MOL ash $(84 \mu \mathrm{m})$, clay $+30 \% \mathrm{~F}(196 \mu \mathrm{m})$, clay $+54 \%(\mathrm{CL}) *$ ash $(283 \mu \mathrm{m})$, and clay $+20 \% \mathrm{~F}+20 \%(\mathrm{CL}) *$ ash $(68 \mu \mathrm{m})$. Figs. 9a-9f show the scanning electron micrographies of the fracture surface on the flexural edge of some ceramics 


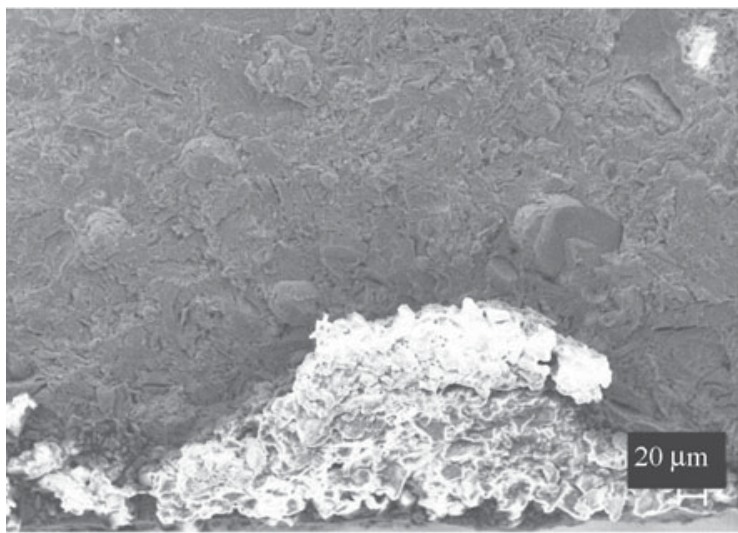

(a)

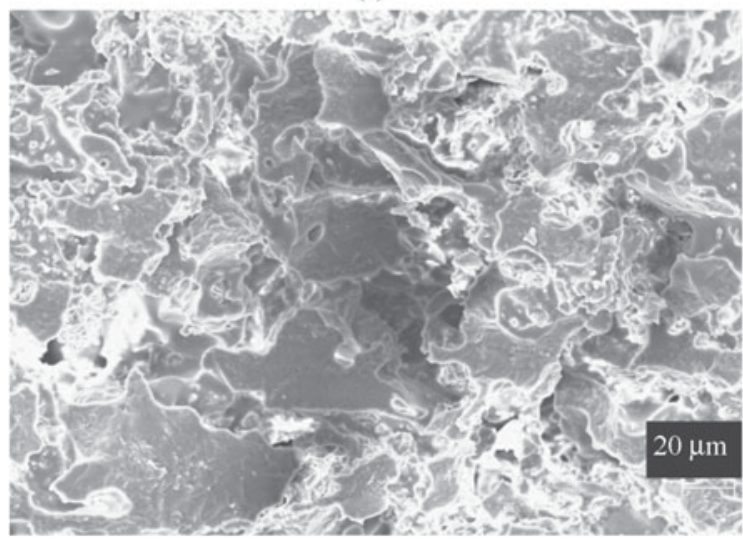

(c)

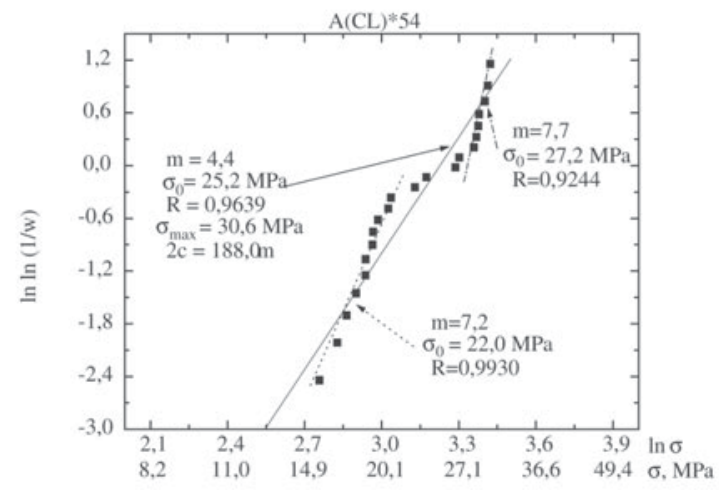

(e)

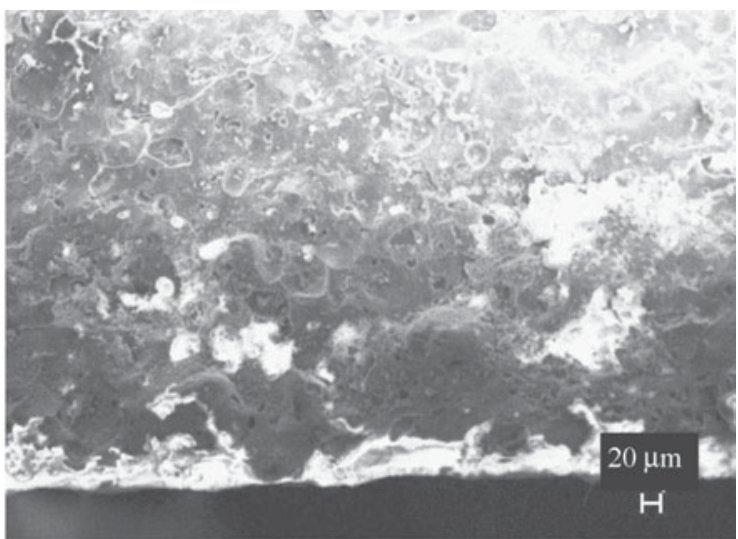

(b)

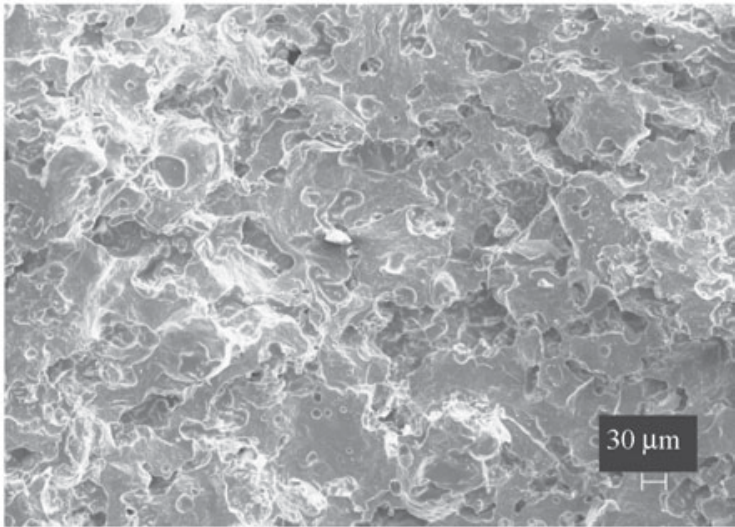

(d)

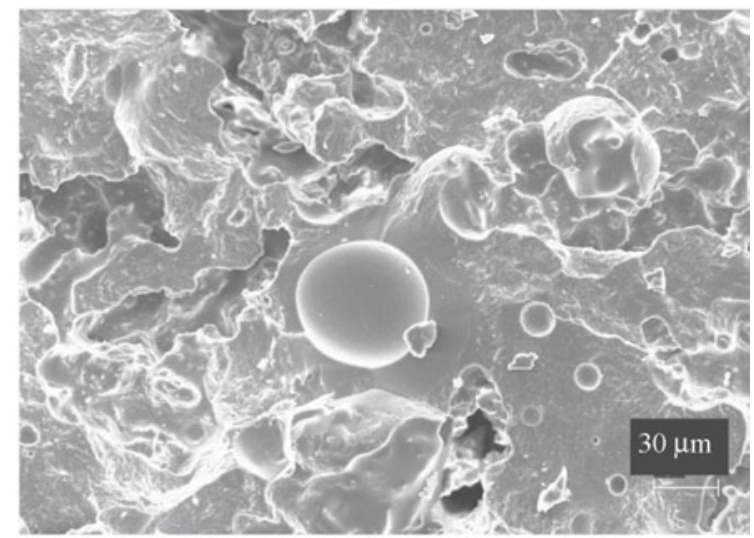

(f)

Figure 9. Scanning electron micrographies of the fracture surface of some ceramics sintered at $1200{ }^{\circ} \mathrm{C}$, and the bimodal Weibull distribution of clay $+54 \%$ (CL)* ash: a) Pure clay; b) clay 20\% F 20\% (CL)*ash; c) clay 54\% (CL)*ash: sample at the lower mode of BWD; d) Clay 54\% (CL)*ash: sample at the higher mode of BWD; e) bimodal Weibull distribution of the clay + 54\%(CL)*ash; f) Clay $54 \%$ (CL)*ash: immiscibility of glass in glass.

sintered at $1200{ }^{\circ} \mathrm{C}$ and the bimodal Weibull distribution of the clay $+54 \%(\mathrm{CL})^{*}$ ash. All ceramics showed a monomodal Weibull distribution except the material prepared with the addition of more than $40 \%$ (CL)* ash. This result is in agreement to the data of Fig. 7 where those com- positions situate in the phase boundaries of the mullite/corundum/leucite region. The microstructure of the pure clay (Fig. 9a) shows an incomplete sinterization in the bulk and some crystallisation in the edge. Clay $+20 \% \mathrm{~F}+20 \%(\mathrm{CL}) *$ ash microstructure (Fig. 9b) shows a high degree of sintering, 
and crystallisation in the bulk and in the edge. X-ray diffraction measurements on this sample showed the following phases: quartz, cristobalite, mullite, corundum, and labradorite $\left.\left(\mathrm{NaO}_{0.4} \mathrm{CaO}_{0.6}\right) \mathrm{Al}_{1.6} \mathrm{Si}_{2.4} \mathrm{O}_{8}\right)$. The material clay + $30 \% \mathrm{~F}$ (not shown in the figure) has an incomplete sintering, and crystallisation only in the edge. Figure 9c shows the microstructure of the clay $+54 \%(\mathrm{CL}) *$ ash for a sample at the lower mode of the Weibull distribution; Fig. 9d refers to the same material at the higher mode. The specimen at the lower mode showed a double region of phases, similar to the double phases in $\mathrm{Si}_{3} \mathrm{~N}_{4}$, a ceramic material that presents a bimodal distribution ${ }^{17,22}$. The double region of phases in this work may be due to the composition close to the phase boundaries of the mullite/corundum/leucite region. Figure 9e shows the bimodal Weibull distribution of clay $+54 \%(\mathrm{CL}) *$ ash and Fig. 9f shows the immiscibility of glass in glass in that material. High-tech methodologies open opportunities to understand high quality red ceramics ${ }^{23}$, particularly the addition of ashes that has been a "black box".

The utilisation of agricultural, industrial or municipal solid waste residues as additive to prepare any kind of materials has to fulfil the requirements of environmental control. Solubilization and leaching tests were performed in the MOL ash and some vitrified ceramics following the Brazilian standard NBR 10006 and NBR 10005, respectively ${ }^{24,25}$. Results of the determination of potentially toxic metals in the extracts are shown in Table 3. The MOL ash does not meet the specifications of NBR 10004 standard $^{26}$. All ceramics fulfil the standard requirements for most elements. This means that the solid residues generated in the BR can be aggregated to the ceramic materials, accomplishing the null pollution processing cycle. Some elements ( $\mathrm{Al}, \mathrm{Cd}$ and $\mathrm{Pb}$ ), present in very low concentrations, presented limits of detection above their concentration requirements due to the low sensitivity of the emission lines used for the determination by ICP-OES. For these elements analysis by graphite furnace atomic absorption spectrometry will be carried out ${ }^{27}$.

The common practice of simply adding sludge and other residues into ceramics for stabilisation of pollutants without quality improvement of the materials properties and with

Table 3. Potentially toxic metals in the solubilized and leached extracts of MOL ash and some vitrified ceramics.

\begin{tabular}{|c|c|c|c|c|c|c|}
\hline \multirow[b]{2}{*}{ Element } & \multicolumn{5}{|c|}{ Solubilization extracts $^{a}(\mathrm{mg} / \mathrm{l})$} & \multirow[b]{2}{*}{$\begin{array}{c}\text { Solubilization } \\
\text { Test }^{b}(\mathrm{mg} / \mathrm{l})\end{array}$} \\
\hline & MOL ash & $\begin{array}{c}\text { Clay }+ \\
13.5 \% \text { MOL ash }\end{array}$ & $\begin{array}{c}\text { Clay + } \\
54 \%(\mathrm{CL}) * \text { ash }\end{array}$ & $\begin{array}{c}\text { Clay }+20 \% \mathrm{~F} \\
+20 \%(\mathrm{CL}) * \text { ash }\end{array}$ & Pure clay & \\
\hline $\mathrm{Ag}$ & $<0.004$ & $<0.05$ & $<0.05$ & $<0.05$ & $<0.05$ & 0.05 \\
\hline $\mathrm{Al}$ & $<1.5$ & $<0.1$ & $<0.1$ & $<0.01$ & $<0.5$ & $<0.2$ \\
\hline As & $<\mathrm{DL}^{c}$ & & Not determined ${ }^{d}$ & 0.05 & & \\
\hline $\mathrm{Ba}$ & $<0.005$ & $<0.01$ & $<0.01$ & $<0.01$ & $<0.007$ & 1.0 \\
\hline $\mathrm{Cd}$ & $<0.007$ & $<0.004$ & $<0.004$ & $<0.005$ & $<0.005$ & 0.005 \\
\hline $\mathrm{Cr}$ (total) & 75 & $<0.05$ & $<0.05$ & $<0.05$ & $<0.05$ & 0.05 \\
\hline $\mathrm{Cu}$ & $<0.12$ & $<0.12$ & $<0.1$ & $<0.05$ & $<0.05$ & 1.0 \\
\hline $\mathrm{Fe}$ & 0.03 & $<0.02$ & $<0.02$ & $<0.02$ & $<0.006$ & 0.3 \\
\hline $\mathrm{Hg}$ & $<\mathrm{DL}^{c}$ & & Not determined ${ }^{d}$ & 0.001 & & \\
\hline $\mathrm{Mn}$ & $<0.001$ & $<0.002$ & $<0.002$ & $<0.001$ & $<0.001$ & 0.1 \\
\hline $\mathrm{Na}$ & 4700 & 1.1 & 1.8 & 1.1 & 1.2 & 200.0 \\
\hline $\mathrm{Pb}$ & $<1.5$ & $<0.2$ & $<0.2$ & $<0.2$ & $<0.1$ & 0.05 \\
\hline $\mathrm{Se}$ & $<\mathrm{DL}^{c}$ & & Not determined ${ }^{d}$ & 0.01 & & \\
\hline \multirow[t]{2}{*}{$\mathrm{Zn}$} & $<0.004$ & $<0.007$ & $<0.006$ & $<0.02$ & $<0.005$ & 5.0 \\
\hline & \multicolumn{5}{|c|}{ Leaching extracts $^{a}(\mathrm{mg} / \mathrm{l})$} & Leaching \\
\hline $\mathrm{Ag}$ & $<0.004$ & $<0.005$ & $<0.005$ & $<0.005$ & $<0.007$ & 5.0 \\
\hline $\mathrm{Ba}$ & $<0.004$ & $<0.01$ & $<0.01$ & $<0.01$ & $<0.005$ & 100.0 \\
\hline $\mathrm{Cd}$ & $<0.005$ & $<0.004$ & $<0.004$ & $<0.004$ & $<0.004$ & 0.5 \\
\hline $\mathrm{Cr}$ (total) & 13.0 & $<0.04$ & $<0.3$ & $<0.06$ & $<0.03$ & 5.0 \\
\hline $\mathrm{Pb}$ & $<1.5$ & $<0.2$ & $<0.2$ & $<0.2$ & $<0.1$ & 5.0 \\
\hline
\end{tabular}

${ }^{a}$ Determination by inductively coupled plasma optical emission spectrometry (ICP-OES); ${ }^{b}$ Maximum allowed limits by NBR 10004 ; ${ }^{c}$ Determination by an independent laboratory Ambiental Laboratórios e Equipamentos Ltda; ${ }^{d}$ Elements not determined because their contents in the raw materials were already lower than the standard specifications. 
no economical benefits is not enough. The present work showed that it is also possible to obtain high-quality ceramics with partial addition of low cost SM/NM ash.

Besides the high quality of the ceramics produced with the addition of a mixture of ash/feldspar, the impact of the Biomass Refinery in the ceramic industry can be evaluated by the following numbers. The national consumption of feldspar is of 350,000 ton/year and the world production is of the order of 10 million ton/year (Italy - 2,700,000 ton/year, Japan - 1,200,000 ton/year, USA - 900,000 ton/year, France - 600,000 ton/year and Spain - 500,000 ton/year) ${ }^{28}$. National MSW production is about $33 \times 10^{6}$ ton/year with an ash content of $6 \%{ }^{29}$. This generates $2 \times 10^{6}$ ton/year of ash, which represent 5.7 times the national feldspar consumption. The processing of only $17.5 \%$ of MSW in the Biomass Refinery is enough to double the feldspar supply. Other biomasses can also be considered: wood residues $\left(85 \times 10^{6}\right.$ ton/year, $1.2 \%$ ash, $1 \times 10^{6}$ ton/year of ash $)$ and sugarcane bagasse and trash $\left(78 \times 10^{6}\right.$ ton/year, $2.5 \%$ ash, $2.0 \times 10^{6}$ ton/year of ash $)^{1}$. Generally, the ash of these biomasses returns to the forest and sugar fields for fertilisation, causing some degree of contamination of the underground water.

\section{Conclusions}

The basic technologies prehydrolysis, furfural production, affluent treatment station, low temperature conversion, combined cycle thermoelectric and ceramic vitrification form the necessary and sufficient technological package for the establishment of an economic and ecological Biomass Refinery. Natural (MOL, agricultural residue, wood, grass) and petroleum polymeric materials (tires, plastics) are processed by the BR. Null pollution concept is achieved with no disposition of solid, liquid or polluted gaseous emissions. In the future $\mathrm{CO}_{2}$ will also be collected and commercialised. The ashes from the BR are not sintered because all process occur in low temperatures. They are SM/NM particles, opening new opportunities for engineered materials (feelers, ceramics and new materials). The BR ashes can partially replace feldspar generating grès-type and porcelain ceramics. The amount of ash can reach millions of ton/year with residual costs. The BR yields low cost cellulignin fuel for sintering industries and allows local production of high-quality ceramics with reduction of freight cost.

\section{Acknowledgements}

The authors wish to thank the use of the SEM - FEG Jeol JSM-6330F electron microscope at the LME/LNLS, Campinas - SP, Brazil. The authors I. de Oliveira and Mônica C. Borlini wish to thank Fapesp for their master fellowship, and M.L.G. Pereira wishes to thank Fapesp for her doctor- ate fellowship. The author Marco A. Marcondes wishes to thank CAPES for the master fellowship.

\section{References}

1. Pinatti, D.G.; Couto L.; Soares, A.G.; Vieira, C.C.; Conte, R.A. Proceedings of the 3rd Meeting of the International Energy Agency- Bioenergy, Task 17- Short-Rotation Crops for Bioenergy, Auburn, USA, p.17, september/ 1999.

2. Bayer, E. Process for Producing Solid, Liquid and Gaseous Fuel from Organic Starting Material US Patent number 5.114.541, may/1992.

3. Biobased Industrial Products: Priorities, Research and Commercialization, National Academy Press, Washington DC, USA, 1999.

4. Soares, A.G. Absorção de Gases em Carvão Ativado de Celulignina, Tese de Doutorado, IFGW, UNICAMP, Campinas, SP, 174 p. , 2001.

5. Pure Energy Corporation:10 CFR Part 490: Alternative Fuel Transportation Program; P-series Fuels, Final Rule DOE: Office of Energy Efficiency and Renewable Energy, Federal Register, v. 64, n.94, p. 26822, may/1999

6. Romão, E.L. Pré-hidrólise da Matéria Orgânica do Lixo Municipal, Dissertação de Mestrado, DEMAR, FAENQUIL, Lorena, SP, 147 p., 2000.

7. Vieira, C.A. Fundamentos da Combustão da Celulignina e suas Aplicações como Combustível de Caldeiras, Turbinas e MHD, Tese de Doutorado, IFGW, UNICAMP, Campinas, SP, 205 p., 2000.

8. Ferreira, J.C. Otimização dos Reatores de Furfural Fabricados com Metais Refratários, Dissertação de Mestrado, DEMAR, FAENQUIL, Lorena, SP, 86 p., 2002.

9. Montanha, R.G.O. Controle Químico da Produção de Furfural pelo Processo de Duas Etapas, Dissertação de Mestrado, DEMAR, FAENQUIL, Lorena, SP, 2002.

10. Oliveira, I. Reciclagem de Pneus através de Conversão em Baixa Temperatura - CBT, Exame de Qualificação de Mestrado, DEMAR, FAENQUIL, Lorena, SP, 2002.

11. Marcondes, M.A. Estudo da Temperatura de Início da Formação de Fase Vítrea nas Cinzas de Biomassa, e Interações dessas com Tubinas a Gás, Dissertação de Mestrado, DEMAR, FAENQUIL, Lorena, SP, 78 p, 2002.

12. Santos, B.C. Adição de Cinzas da Celulignina em Placas Cerâmicas, Dissertação de Mestrado, DEMAR, FAENQUIL, Lorena, SP, 2002.

13. Joseph, R.W. System for Burning Biomass to Produce Hot Gas, US Patent number 5.720.165, february/1998.

14. Bioten Process-Renewable Electric Energy, Knoxville, TN, USA, 13 p.,1999.

15. Miles, T.R.; Miles Jr, T.R.; Baxter, L.L.; Bryers, R.W.; Jenkins, B.M.; Oden, L.L. Summary Report on Alkali 
Deposits Found in Biomass Power Plants- A Preliminary Investigation of Their Extent and Nature, National Renewable Energy Laboratory, CO, USA, 120 p., april/ 1995.

16. Kingery, W.D.; Bowen, H..K.; Uhlmann, D.R. Introduction to Ceramics, Wiley \& Sons, New York, USA, p. 533, 1976.

17. Richerson, D.W. Modern Ceramic Engineering, Marcel Dekker, New York, USA, p. 669, 1992.

18. Basegio, T.M.; Berutti, F.A.; Bergmann, C.P. Anais do $45^{\circ} \mathrm{CBC}$, Florianópolis, SC, CD-ROM 0401501, junho/ 2001.

19. Basegio T.M. ; Berutti, F.A.; Bergmann, C.P. Anais do $14^{\circ}$ CBCIMAT, São Pedro, SP, CD-ROM 12801, dezembro/2000.

20. Oliveira, H.A.; Cunha, E.S.; Gibo, R.M.; Bressiani, J.C. Anais do $43^{\circ} \mathrm{CBC}$, Florianópolis, SC, CR-ROM 02001 , julho/1999.

21. Vieira C.M.F. Vitrificação de Argilas Vermelhas de Campos dos Goytacazes, RJ, Dissertação de Mestrado, CCT-LAMAV, UENF, Campos dos Goytacazes, RJ, 1997.

22. Absi, J.; Glaudus, J.C. Numerical separation of bi-mo- dal strength distribution, J. European Ceramic Society, 22, 2002, p 593-601.

23 Xavier, C. Anais do $14^{\circ}$ CBCIMAT, São Pedro, SP, CDROM 050001, dezembro/2000.

24. NBR 10006 - Solubilização de Resíduos SólidosProcedimentos, 2 p., setembro/1987.

25. NBR 10005 - Lixiviação de Resíduos SólidosProcedimentos, 2 p., setembro/1987.

26. NBR 10004 - Resíduos Sólidos-Classificação, 48 p., setembro/1987.

27. Borlini, M.C. Estabilização de Metais Pesados nas Cinzas e em Cerâmicas Vermelhas Preparadas com Adição de Cinzas do Lodo e da Celulignina do Processo de Pré-hidrólise da Matéria Orgânica do Lixo, Dissertação de Mestrado, DEMAR, FAENQUIL, Lorena, SP, 189 p., 2002.

28. Coelho, J.M.; Suslick, S.B.; Souza, M.C.A.F. Anais do $43^{\circ} \mathrm{CBC}$, Florianópolis, SC, CD-ROM 07601, junho/ 1999.

29. D’Almeida, M.L.O.; Vilhena, A. Lixo MunicipalManual de Gerenciamento Integrado, 2a edição, CEMPRE/IPT, São Paulo, SP, p.3, 2000. 